Tropical Forests \& Climate Change Adaptation

\title{
Forest policies and forest resource flow in Burkina Faso, Ghana and Mali \\ Conflicting or consistent for adaptation to climate change?
}

\author{
Fobissie B. Kalame, Monica Idinoba, Maria Brockhaus, and Johnson Nkem \\ Environmental Services and Sustainable Use of Forest Programme, Center for International Forestry Research \\ (CIFOR), West Africa Regional office, Ouagadougou, Burkina Faso
}

This policy brief analyses forest policies in Burkina Faso, Ghana and Mali and their implication for adaptation and conflicts under climate change. It presents results of studies undertaken by Tropical Forest and Climate Change Adaptation (TroFCCA). The policy brief tracks the flow of specific forest ecosystem goods and services and the potential for social conflicts in the form of disagreement. Divergent views, arguments and clashes are identified.

\section{Policy Conclusion}

- Governance is central to adaptive management of forest ecosystem goods and services. Different institutions and actors have differing interests in the same forest ecosystem goods and services characterised by conflicting views.

- There is a growing interest in finding ways to include well designed and articulated climate change adaptation strategies into national forest and other development policies and programmes that increase the adaptive capacity in one community or country without creating more vulnerability in another.

- Rights and access to resources shape local adaptation capacity and response options to climate change. Government policies in Burkina Faso, Ghana and Mali are inflexible with standardised rules on access and tenure rights applicable to all forest resources irrespective of the nature of the provided goods and services, their location or existing customary settings and other prevailing circumstances. This makes it difficult for some forest-dependent communities to use forest resources for adaptation.

- Decision making processes regarding forest ecosystem goods and services lack transparency, active participation and the views of the poor.

- Non-timber forest products are pivotal to livelihoods dependent on natural resources and especially for adaptation responses to climate change, but policies and strategies for their management and development are lacking. 


\section{Adaptation, Forest Policies and Conflicts}

The United Nations Framework Convention on Climate Change emphasises adaptation policies and activities that promise to address the special needs and concerns of Non-Annex I Parties (i.e. developing countries that are not yet obliged to reduce emissions). These adaptation activities must be carefully planned and decided upon at appropriate regional, national and community levels, regarding how best to reduce vulnerability to climate impacts, and do it in the most effective manner. A broad perspective is needed, otherwise an adaptation action at national, district or local level in one country could decrease adaptability in another. Such opposing adaptation situations, especially in the utilisation of forest and other natural resources, often lead to tension and conflict between different stakeholders such as farmers and cattle herders, and may also affect local, national and even regional authorities.

Forest resources are used in very different ways in West Africa across household, local and national levels as adaptation measures to drought-induced environmental degradation and to enhance livelihood strategies. Nonetheless, the existing national forest policies of Burkina Faso, Ghana and Mali lack clear policies on climate change, and therefore they are insufficient and not up-to-date to deal with the present global climate change crisis (Box 1).

\section{Situation Analysis of Burkina Faso, Ghana and Mali}

Some of the national forest policies and forest strategies of these countries are intended to improve livelihoods and to reduce environmental

\section{Box 1. How adequate are the existing national forest policies for climate change adaptation?}

The national forest policies of Burkina Faso, Ghana and Mali generally focus on the environment without any specific policy statement and strategy directly aimed at addressing climate change adaptation issues. These policies focus on biodiversity conservation and sustainable forest management, decentralisation processes, and improved human and environmental wellbeing.

Inadvertently, the United Nation Framework Convention on Climate Change (UNFCCC) came into force in 1994 just when most of the current national forest policies in West Africa were being formulated:

- Burkina Faso ratified UNFCCC in 1993, became a member in 1994 and formulated La Politique Forestière Nationale in 1995.

- Ghana formulated its present Forest and Wildlife Policy in 1994, ratified and became a member of UNFCCC in 1995.

- Mali ratified UNFCCC in 1994 and became a member in 1995, the same year La Politique Forestière Nationale was formulated.

Earlier initiatives that resulted in the revision and adoption of these forest policies began long ago. In the case of Ghana, this started even before the creation of the intergovernmental panel on climate in 1988. At that time, there was not much awareness of or concern about climate change and the role of forests in the process. Climate change has emerged today as a major threat to achieving sustainable provisioning of forest ecosystem goods and services and also in attaining the UN Millennium Development Goals numbers 1, to eradicate extreme poverty and hunger, and 7 , to ensure environmental sustainability. Despite the shift in paradigm with new scientific information on the role of forests in achieving these global development targets, forest is still unmentioned in any of the Poverty Reduction Strategy Papers of Burkina Faso, Ghana and Mali. These are disturbing concerns in tackling poverty reduction and environmental issues especially under climate change challenges for tropical countries that largely depend on forest resources for national development and household livelihood. 

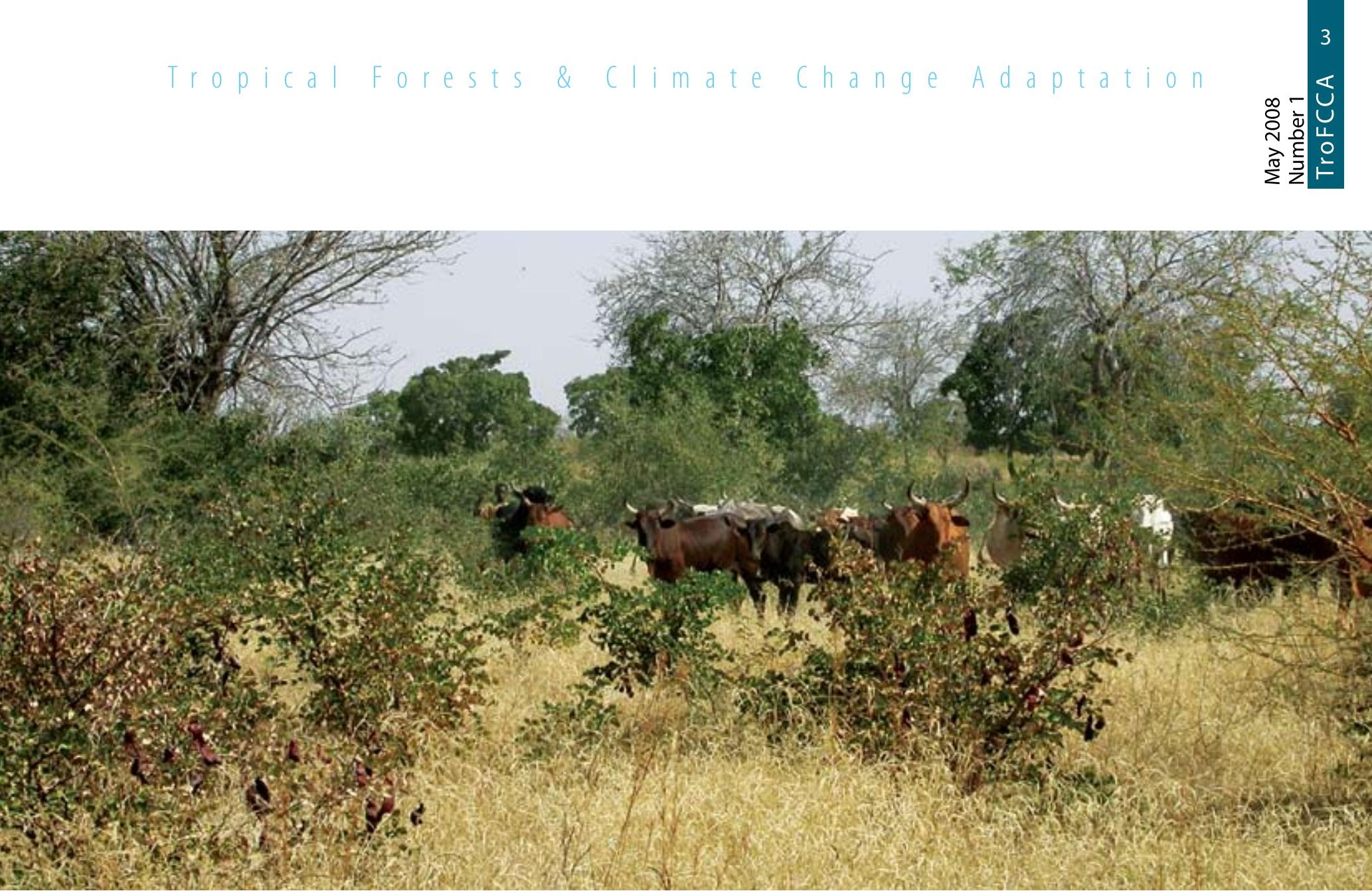

Livestock in savanna woodlands, Burkina Faso (Photo by Daniel Tiveau)

degradation that could potentially enhance both livelihood and ecosystem adaptation to the impacts of climate change. These policies have to be better targeted, however, and reframed with climate proofing for future scenarios. In their current forms, they are increasingly causing insecurity and conflicts as summarised below.

\section{Conflicts in Reforestation and Afforestation Activities}

Drought and desertification coupled with human activities are increasing the depletion of forest resources and environmental degradation in Burkina Faso, Mali and the northern region of Ghana. Reforestation and afforestation initiatives by government, private entities, communities and at household level involving planted and natural regeneration, including large-scale industrial plantations, constitute major response activities, which could pass for adaptation strategies in these countries since the droughts of the 1970s. These strategies, however, have their limitations and in some cases have resulted in conflicts among stakeholders, Ghana being a case in point.

The government of Ghana is keen on expanding teak plantations, but is doing so without properly and explicitly establishing the rights and obligations of the concerned parties with regards to ownership of both the plantations and the land used in their establishment. This blurry situation easily leads to land right conflicts among families, farming communities and Chiefs, thereby disrupting social structures and institutions. Sève et al. (2006) explained the occurring conflicts in the case of a teak plantation project in Abutia Kpota with the lack of a legally signed document transferring land rights from family and community holdings to the project.

These land use conflicts and land tenure insecurity have a high potential for reducing the adaptive capacity of any community, especially the poor and women, because adaptive capacity is determined partly by the rights to 


\section{Box 2. The risk of maladaptation for natural resources-dependent poor}

Tree tenure is generally unfavourable to local communities in Ghana because a substantial part of the tree resource base is actually alienated from the farmers who are in direct contact with this resource. This is because the Timber Resource Management Amendment Act (Act 617) of 2002 does not allow the forest-dependent poor to harvest timber from any land, including their farmlands, without legally registering and holding a timber right. Getting authorization and timber utilisation contracts is, however, highly complicated for the local communities, and they now see this as a removal of their rights and benefits and an expropriation of their lands and forest resources (Kotey et al. 1998). Farmers need these tree resources for their livelihood but find no incentives to preserve and sustainably manage them on their lands, partly because they rarely own the land, but mainly because they do not own the tree and are compensated inadequately for damages incurred by logging on their farmlands. As a result, the mismanagement of these forest resources by farmers leads to maladaptation in response to climate impacts.

utilise forest and land resources for livelihood security and food in response to drought- or flood-induced famine. In this case, tenure insecurity is liable to turn adaptation into maladaptation (Box 2).

\section{Charcoal Production: The State versus the People}

Charcoal production and other human activities coupled with the impacts of drought and desertification are perceived to cause accelerated environmental degradation and desertification in Burkina Faso, Ghana and Mali-a perception not necessarily supported by scientific evidence. There exist public policies based on perceptions rather than science-based evidence (DEAR 2005), whereby Chiefs and District Assemblies (DAs) in some areas of Ghana (also in Burkina Faso) ban charcoal production for use as a household energy although alternative energy sources are seldom provided. Charcoal production provides alternative off-farm income activities for many local households and it drives the trade links between rural and urban communities. The banning of charcoal production has provoked conflicts and accusations among various interest groups. For example:

- Charcoal producers in the Kintampo North and Kintampo South districts in Ghana (Amanor et al. 2005) and in Burkina Faso (MECV 2005) are accused of catalysing environmental degradation by causing bushfires in the forest and cutting trees along riverbanks. Charcoal producers, however, argue that they use fast coppicing and pyrogenic species and that timber merchants and chainsaw operators authorised by Chiefs are responsible for the bushfires and environmental degradation.

- Conflicts often arise (in Ghana for example) between charcoal producers and farmers over the rights to trees and between Chiefs and DAs that have the custody rights to regulate charcoal (Amanor and Brown 2003). In principle, Chiefs have the authority to issue exploitation rights for non-timber products to any person, while DAs are responsible for developing environmental management regulations which in some situations are deliberately used to regulate and even ban charcoal production, thus overturning the Chiefs' power under the pretext that it encourages desertification.

Like any other interest group, charcoal producers believe they have the right to their livelihood activity. Thus, national policy responses by authorities to either climate change or other drivers for environmental degradation need to consider the 
tradeoffs and implications of each measure to avoid new crises. Specifically, a regulatory framework is needed that (a) limits the application of (intended as well as unintended) inappropriate and antipoor policies implemented by Chiefs, DAs, forestry officers and the state and (b) strengthens participatory approaches that integrate the views of farmers and charcoal burners in the decision making processes to promote a sustainable charcoal production.

\section{Access to Forest Resources for Adaptation}

Climate change and some aspects of existing forest policies increasingly undermine livelihood security by reducing access to forest resources that are important to sustaining livelihoods. The Ghana government's Forest Protection Amendment Act (Act 624) of 2002 restricts community access to forest products within forest reserves. By contrast, government policies in Burkina Faso (Articles 55-59 of the Forestry Code) and Mali allow access rights to communities for non-timber forest products within forest reserves especially for subsistence purposes (Box 3). These different access rights determine the resource base communities can act upon to adapt during climatic shocks.

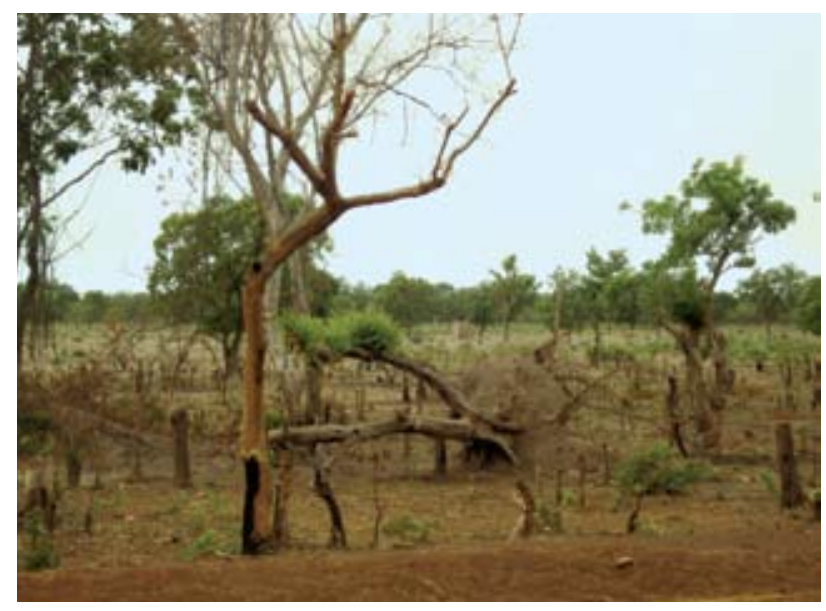

Clearing trees for charcoal production, Ghana (Photo by Fobissie B. Kalame)

Some policies and regulations that restrict access and user rights tend to encourage the management and provision of particular ecosystem services, however, and are necessary to halt the threat of species extinction. In Mali, the cutting of trees and clearing of vegetation is prohibited around water sources and courses, and also around sand dunes and hills that are at risk of erosion. Tree cutting is only permitted beyond $25 \mathrm{~m}$ from these areas. Policies and regulations prohibiting the cutting of trees in these areas will rather help in stabilising sand dunes and reducing the vulnerability of communities to the threats posed by the encroaching desert.

\section{Box 3. Non-timber forest products and climate change adaptation}

In many parts of West Africa, forest products are central to adaptation, which in turn ensures that livelihoods are not threatened by climate change. These non-timber forest products include deadwood, wild fruits, vegetables, fodder and medicinal plants. They represent the subsistence lifelines and economic base of many forest-dependent communities and act as buffer and safety nets (CIFOR 2006) during periods of climateinduced crop failures and famine especially in marginal agricultural areas. Climate change is already affecting these forest goods threatening livelihoods as well as limiting the implementation of national development programmes.

Despite the central role of forests in local adaptive response, there are no clear policies linking climate change adaptation and non-timber forest products. The lack of clearly articulated financial benefits of non-timber forest products (except for bushmeat, firewood and sheabutter) to the gross domestic products of Burkina Faso, Ghana and Mali has led to insufficient recognition in national planning of their contributions to local livelihoods adaptation response measures. 


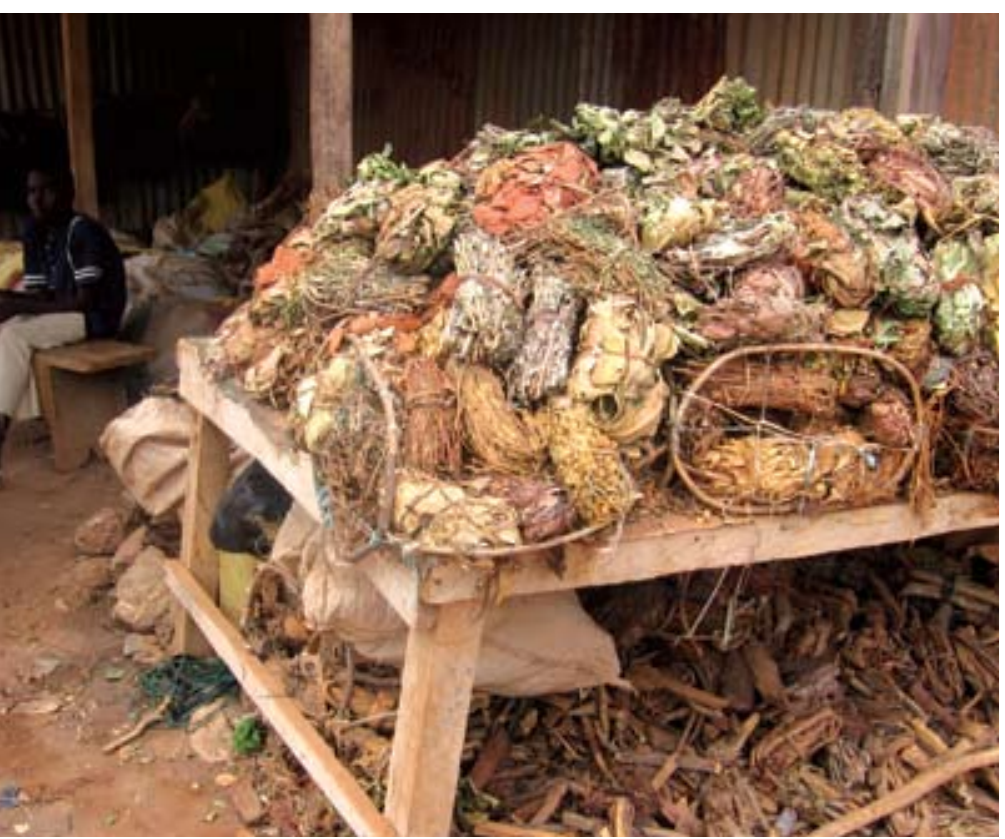

Non Timber Forest Products(NTFPs), Medicinal plants (Photo by Monica Idinoba)

Besides the need for a national regulatory framework, it is important for access right policies to be place-based, contextual, locally adapted and highly flexible in application and compliance.

\section{Decentralisation Processes}

The decentralisation of natural resource management provides opportunities for adaptation to climate variability and climate change impacts on natural resources and natural resourcedependent communities in West Africa (Elasha et al. 2007). - This situation could be applicable to farming communities in Burkina Faso and Mali that are using integrated land and forest management approaches. It could, however, exacerbate vulnerability in pastoral communities as most grazing corridors around forest areas have been mapped out for permanent farming activities, thereby restricting pastoral mobility for grazing as an adaptation response. This limitation again nurses the potential for conflict between farmers and herders as occurred in August 2007 at Gogo,
Central South Region of Burkina Faso, and in the Niger Delta in Mali between transhumant Peuls and Rimaibes farmers over contested grazing territory, which led to the loss of lives (Maïga and Diallo 1998). In the Central West and East of Burkina Faso, farmlands and grazing corridors have been expropriated by agribusinesses with the financial resources for establishment of commercial export crops like cotton. These ambitions have resulted in extensive forest clearing, sometimes displacing traditional farmers and pastoralists who originally used the land (Ouédraogo 2003). In search of livelihood, there is forced migration of activities increasing the pressure on the remnant forest and starting new cycles of environmental degradation and conflicts.

These examples highlight some of the issues in the process of decentralisation that need to be overcome in improving resource governance and livelihood as a means to enhance the adaptive capacity of local communities. Results from a TroFCCA case study in southwest Burkina Faso indicate that decentralisation offers strong opportunities for design and implementation of adaptation strategies under growing institutional flexibility, higher responsiveness and selective planning and implementation at local level. Success, however, can be hindered by lack of learning capacities, lack of knowledge, growing conflict potential among resource users and a biased agenda setting for adaptation due to perceived tradeoffs among the various sectors.

\section{The Way Forward}

The above discussion underscores the limitations of current forest policies in the three study countries in West Africa. There is a need for a comprehensive review and reform of national forest policies and 
strategies in West Africa as climate change emerges as the greatest challenge humankind faces in the 21 st century. Such integrative reforms are crucial to ensuring national development and peaceful coexistence of the various stakeholders. Policy reform will not only reduce negative impacts of climate change, but also have the potential of creating good opportunities for adaptation.

A participatory action approach that engages all the stakeholders in a dialogue will provide the opportunity to negotiate acceptable outcomes and compromises among stakeholders in balancing their multiple interests in the policy process, because active participation of all stakeholders in decision making processes will (a) help eliminate the risk of any single group dominating or forcing its own agenda and (b) secure active involvement of local communities. Steps should therefore be taken to ensure

- active involvement of local resource users and reflection of their views in the decision-making processes at both local and state levels;

- creation of a multistakeholder and crosssectoral platform for integrated land use planning;

- improved resource ownership and user rights, especially the rights of smallholders and communities;

- enforcement of mechanisms for conflict mediation among resource users;

- encouragement of political will by politicians and elites to support local activities that promote forest and natural resources for adaptation responses; and

- encouragement of implementation of good governance (accountability, transparency, partnership).

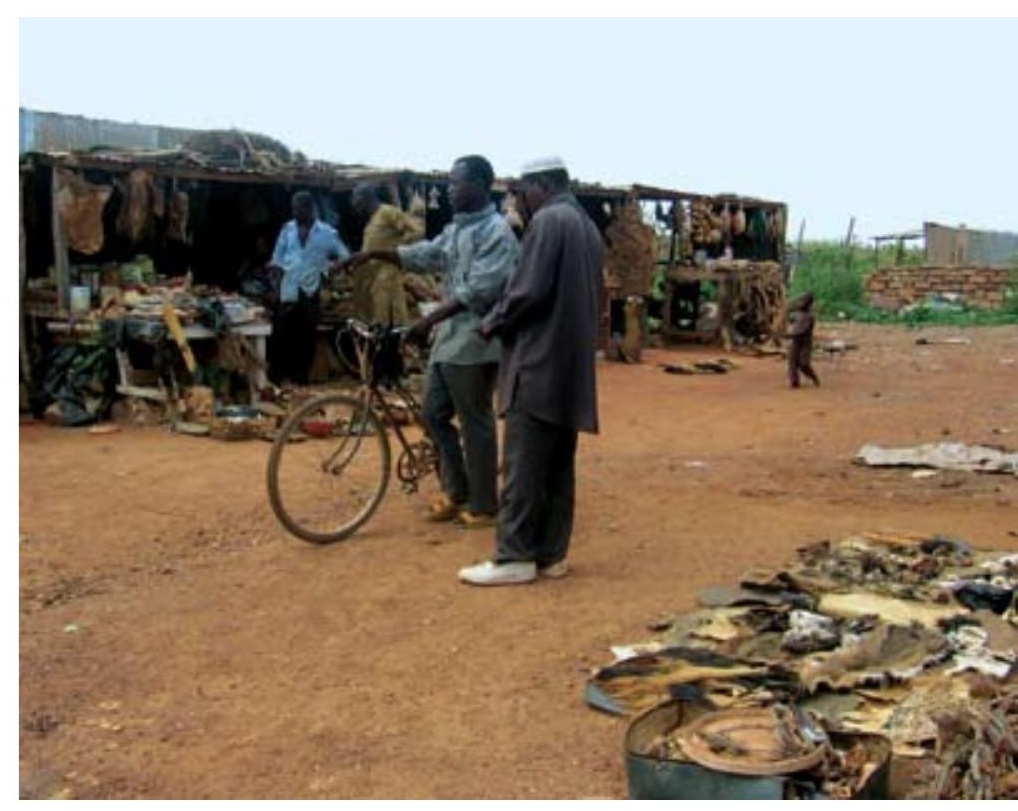

Non Timber Forest Products, Medicinal products in the market (Photo by Monica Idinoba)

Some of the new policy approaches in integrating climate change adaptation into forest policies include forging links to the ongoing Africa Forest Law Enforcement and Governance process, and also the initiative for a common West African regional forest policy in which Burkina Faso, Ghana and Mali are members. The integration of an adaptation outlook into the existing livelihood improvement aspects of these ongoing forest policy processes has the potential to reduce conflicts and improve the resilience of communities.

\section{Acknowledgement}

This document has been produced with the financial assistance of the European Union. The contents of this document are the sole responsibility of the authors and can under no circumstances be regarded as reflecting the position of the European Union. We acknowledge the useful comments from reviews by David Brown of the Overseas Development Institute, Carmenza Robledo and Tamara Levine of Intercooperation and Louis Sawadogo of Centre National de Recherche Scientifique et Technologique Burkina Faso. 


\section{References}

Amanor, K. and Brown, D. 2003 Making environmental management more responsive to local needs: decentralisation and evidence-based policy in Ghana. ODI Forestry Briefing 3.

Amanor, K., Osei, E. and Gyampoh, K. 2005 Charcoal burning in the Kintampo districts: policies, environment and livelihood issues. Workshop held at Agricultural Department, Kintampo North District, 29 June 2005. Decentralised Environmental Action Research Project.

CIFOR. 2006 The wealth of dry forests: can sound forest management contribute to the Millennium Development Goals of Sub-Saharan Africa? Forest Livelihood Brief No. 5.

DEAR. 2005 Charcoal burning in the Kintampo districts: policies, environment and livelihood issues. Workshop held at Agricultural Department, Kintampo North District, 29 June 2005. Decentralised Environmental Action Research.

Elasha, O.B., Medany, M., Niang-Diop, I., Nyong, T., Tabo, R. and Vogel, C. 2007 Background paper on impacts, vulnerability and adaptation to climate change in Africa, for the workshop on adaptation implementation of decision 1/CP10 of the UNFCCC Convention. Accra, Ghana, 21-23 September 2006.

Kotey, E.N.A., Francois, J., Owusu, J.G.K., Yeboah, R., Amanor, K.S. and Antwi, L. 1998 Falling into place. Ghana Policy that Works for Forests and People Series No. 4. International Institute of Environment and Development, London.

Maïga, I. and Diallo, G. 1998 Land tenure conflicts and their management in the 5th region of Mali. IIED Issue Paper 76.

Ministère de l'Environnement et du Cadre de Vie (MECV) 2005 Strategie nationale et plan d'action de la filière charbon de bois. Burkina Faso.

Ouédraogo, M. 2003 New stakeholders and the promotion of agro-sylvo pastoral activities in southern Burkina Faso: false start or inexperience? London, IIED. Issue Paper No. 118.

Sève, J.E., Bergqvist, A. and Dourojeanni, M.J. 2006 Ex-post evaluation project PD 48/98 Rev. 1 (F) Reforestation of the Abuti Plains by indigenous communities in the Volta Basin (Ghana).
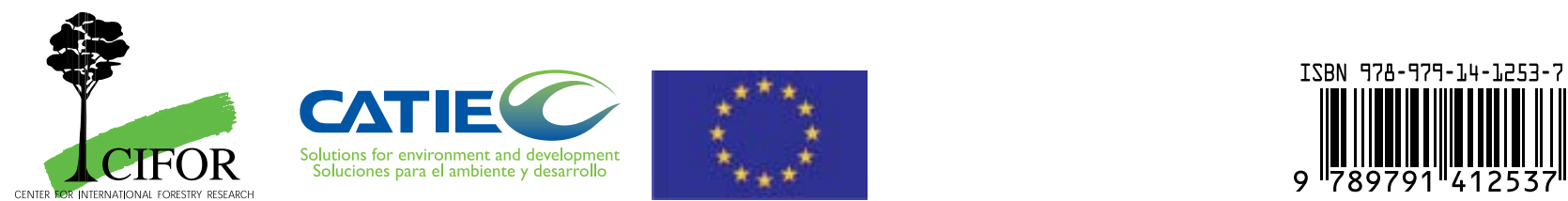

\section{Center for International Forestry Research}

Jl. CIFOR, Situ Gede, Sindang Barang,

Bogor Barat 16115, Indonesia

Tel.: +62 (251) 622622; Fax: +62 (251) 622100

E-mail: cifor@cgiar.org

Cover photos by F. Kalame and M. Idinoba

Web site: http://www.cifor.cgiar.org

This document has been produced with the financial assistance of the European Union. The contents of this document are the sole responsibility of the authors and can under no circumstances be regarded as reflecting the position of CIFOR and the European Union. 